\title{
Revision of Dioncopseudobenedenia Yamaguti, 1965 including the description of $D$. ancoralis sp. n. (Monogenea: Capsalidae) from Pacific acanthuroid teleosts
}

\author{
Marty R. Deveney ${ }^{1}$ and Ian D. Whittington ${ }^{2,3,4}$ \\ ${ }^{1}$ SARDI Aquatic Sciences, South Australian Research and Development Institute, P.O. Box 120, Henley Beach, South Australia \\ 5022, Australia; \\ ${ }^{2}$ Monogenean Research Laboratory, Parasitology Section, The South Australian Museum, North Terrace, Adelaide, South Australia \\ 5000, Australia; \\ ${ }^{3}$ Marine Parasitology Laboratory, School of Earth and Environmental Sciences (DX 650 418), The University of Adelaide, North \\ Terrace, South Australia 5005, Australia; \\ ${ }^{4}$ Australian Centre for Evolutionary Biology and Biodiversity, The University of Adelaide, North Terrace, Adelaide, South \\ Australia 5005, Australia
}

\begin{abstract}
Dioncopseudobenedenia Yamaguti, 1965 (Monogenea: Capsalidae) is redefined. Dioncopseudobenedenia kala Yamaguti, 1965 (type species) is redescribed from type material from Hawaii and from new specimens from Heron Island, Queensland, Australia and New Caledonia. We made detailed observations on D. macracantha Yamaguti, 1968 from type material from Hawaii, and from new material from Heron Island and New Caledonia. Dioncopseudobenedenia ancoralis sp. $\mathrm{n}$. is described from the gill chamber of Siganus lineatus (Valenciennes) from Green Island and Heron Island, Australia and from New Caledonia. This study confirms that only one pair of large central sclerites is present on the haptor in Dioncopseudobenedenia species. The male copulatory organ in species of Dioncopseudobenedenia is a penis contained in a fluid-filled space (= penis canal) with weakly muscular walls. Dioncopseudobenedenia kala and D. ancoralis bear a sclerite at the tip of the penis. In D. macracantha, the structure of the penis, which has no terminal sclerite, indicates it may combine the functions of a penis and a cirrus. Dioncopseudobenedenia is compared with Calicobenedenia Kritsky et Fennessy, 1999, the other capsalid genus with a single pair of large sclerites on the haptor. The large haptoral sclerites in species of Dioncopseudobenedenia resemble accessory sclerites, whereas those of C. polyprioni Kritsky et Fennessy, 1999 resemble hamuli. Observations of oncomiracidia confirmed that the large haptoral sclerites in D. kala are accessory sclerites. Haptoral morphology suggests that different Dioncopseudobenedenia spp. employ different means of attachment. Mating behaviour was observed twice between two different pairs of $D$. kala specimens from Heron Island. Two preserved specimens from Nouméa, New Caledonia had structures near the dorsal vaginal pore that we interpret as spermatophores. This is the first report of spermatophores in a capsalid inhabiting the gill chamber. The geographic distribution of Dioncopseudobenedenia spp. is discussed.
\end{abstract}

Keywords: Platyhelminthes, monogenean fish parasites, taxonomy, Benedeniinae, Acanthuroidei, Hawaii, Great Barrier Reef, New Caledonia

Some of our previous studies have revised genera of capsalid monogenean (platyhelminth) parasites in the Benedeniinae Johnston, 1931: Metabenedeniella Yamaguti, 1958 (see Horton and Whittington 1994); Neobenedenia Yamaguti, 1963 (see Whittington and Horton 1996); Benedenia Diesing, 1858 (see Whittington et al. 2001, Deveney and Whittington 2010, Whittington and Deveney in press) and Menziesia Gibson, 1976 (see Whittington et al. 2001). Here, another benedeniine genus, Dioncopseudobenedenia Yamaguti, 1965, is reviewed. Whittington and Horton (1996) commented that
Neobenedenia, species of which are characterised by the absence of a vagina, might have become a repository for benedeniines in which the vagina had been overlooked. We considered it possible that Dioncopseudobenedenia, characterised by Yamaguti (1965) by the absence of both pairs of hamuli such that the haptor bears only accessory sclerites and hooklets, may comprise some benedeniine species with "cryptic" (i.e. small and/or difficult to distinguish) hamuli. A precedent for this exists elsewhere in the Monogenea; Chisholm and Whittington (1995) observed tiny hamuli in two species of Dendromonocotyle Hargis,

Address for correspondence: M.R. Deveney, SARDI Aquatic Sciences, South Australian Research and Development Institute, and Marine Innovation South Australia, P.O. Box 120, Henley Beach, South Australia 5022, Australia. Phone: ++61 82075434 ; Fax: ++61 882075406 ;

E-mail: marty.deveney@sa.gov.au 
1955 (Monocotylidae) that were previously considered to lack these sclerites. A re-examination of Dioncopseudobenedenia and its constituent species was further warranted because Kritsky and Fennessy (1999) described Calicobenedenia polyprioni Kritsky et Fennessy, 1999, another capsalid bearing only one pair of large haptoral sclerites.

\section{MATERIALS AND METHODS}

Mounted specimens of Dioncopseudobenedenia were borrowed from the following museum collections: Harold W. Manter Laboratory of Parasitology (HWML), W 529 Nebraska Hall, University of Nebraska State Museum, University of Nebraska - Lincoln, Lincoln, NE 68588-0514, USA (contact: Agustín Jiménez-Ruiz, fruiz@unlserve.unl.edu); Meguro Parasitological Museum (MPM), 1-1 Shimomeguro 4-Chome, Meguro-ku, Tokyo 153-0064, Japan (contact: Jun Araki or Takashi Iwaki at the postal address provided); Queensland Museum (QM), P.O. Box 300, South Brisbane, Queensland 4101, Australia (contact: Robert Adlard, RobertAd@qm.qld.gov.au); United States National Parasite Collection (USNPC), Beltsville, MD 20705, USA (contact: Patricia Pilitt, ppilitt@ars.usda.gov).

Live material of some species of Dioncopseudobenedenia was obtained from teleost fishes speared at Heron Island, Queensland, Australia $\left(23^{\circ} 27^{\prime} \mathrm{S}, 151^{\circ} 55^{\prime} \mathrm{E}\right)$ at the southern tip of the Great Barrier Reef during July 1999 and January-February 2000. Teleosts were identified using Randall et al. (1997) and their taxonomic validity and authorities were assessed using Nelson (2006) and Froese and Pauly (2011). The fish classification adopted by Nelson (2006) is followed. Fish and parasites were sampled, processed and recorded as described by Deveney and Whittington (2010). Larvae were sampled and viewed as described in Whittington et al. (1994).

After preparing this paper, material from hosts off New Caledonia was kindly made available by Professeur J.-L. Justine (Muséum National d'Histoire Naturelle, Paris, France), which we incorporated into our investigation. Material from New Caledonia was stained with carmine and prepared following Justine (2005). In text and the table, measurements are in $\mu \mathrm{m}$ unless stated otherwise, presented as the range with the mean in parentheses. Where measurements are paired sets separated by a multiplication sign, the first is length, the second width. One specimen of D. kala killed in boiling seawater was fixed unflattened in $10 \%$ buffered neutral formalin and processed and viewed for scanning electron microscopy (SEM) following Whittington et al. (2001). Capsalid terminology follows Whittington et al. (2001). Terminology and definitions for male copulatory organs follows Whittington and Kearn (2009a).

New material from the present study is deposited in the Muséum National d'Histoire Naturelle [MNHN], Paris, France (contact: Jean-Lou Justine, justine@mnhn.fr), in the QM (see above for details) and in the Australian Helminthological Collection (AHC) of the South Australian Museum [SAMA], Parasitology Section, North Terrace, Adelaide, South Australia 5000, Australia (contact: Leslie Chisholm, leslie.chisholm@samuseum.sa.gov.au).

The following material was examined for comparative purposes: Calicobenedenia polyprioni - USNPC No. 88272 (paratype) (3 slides, 1 mounted haptor, 2 whole specimens) ex body surfaces of Polyprion americanus (Bloch et Schneider), Azores, Portugal; USNPC No. 88270 (paratype) (1 slide, 1 whole specimen) ex body surfaces of $P$. americanus, Blake Plateau, USA; USNPC No. 88271 (paratype) (7 slides, 2 mounted haptors, 6 whole specimens) ex body surfaces of $P$. americanus, Blake Plateau, USA.

\section{RESULTS}

Capsalidae Baird, 1853

Benedeniinae Johnston, 1931

\section{Dioncopseudobenedenia Yamaguti, 1965}

Revised generic diagnosis. Capsalidae, Benedeniinae sensu Whittington et al. (2001). Single pair of median sclerites (= accessory sclerites) near, or slightly posterior to, haptor centre. Haptor margin either thin, scalloped marginal valve (D. kala, Figs. 1A, 2C; D. macracantha, Figs. 7, 8C) or more substantial structure comprising many individual cup-like loculi (new taxon, Figs. 9A, 11). Anterior attachment organs almost circular, divided into anterior glandular and posterior muscular regions. Pharynx muscular with intrinsic gland cells. Glands of Goto large or very large, in posterior angle between testes. Vas deferens expands to form seminal vesicle near anterior margin of testes. Male copulatory organ a penis lying in penis canal with weakly muscular walls. Distal tip of penis armed with sclerite in D. kala and new taxon; sclerite absent in $D$. macracantha. Male accessory gland supplies single accessory gland reservoir via two sets of fine ducts, one entering posteriorly, one entering lateroanteriorly; musculature of wall of accessory gland reservoir merges with proximal musculature of penis canal wall. Genital pore common, immediately posteroventral to left anterior attachment organ. Uterus short, joining penis canal approximately halfway between proximal end of penis and common genital pore. Vaginal pore posterodorsal to common genital pore. Eggs tetrahedral with single long appendage. Parasites of gill chambers of acanthuroid marine teleosts in Pacific Ocean. Type species: Dioncopseudobenedenia kala Yamaguti, 1965. Other species: D. macracantha Yamaguti, 1968, new taxon described below.

Remarks. Yamaguti $(1965,1968)$ outlined the anatomy of Dioncopseudobenedenia spp. well. In capsalids, the male copulatory organ can be a protrusible muscular penis, or an eversible cirrus (Whittington et al. 2001). Yamaguti $(1965,1968)$ described the "cirrus pouch" (= penis canal) as "containing" the "prostatic reservoir" (= accessory gland reservoir). Our study of type specimens and other material of Dioncopseudobenedenia spp. indicates that the structure of the male copulatory organ of $D$. macracantha differs from that of $D$. kala. Observations of living specimens indicate that the male copulatory organ of $D$. macracantha may combine the functions of a 'penis' and a 'cirrus' similar to that described for two species of Neoentobdella Kearn et Whittington, 2005 


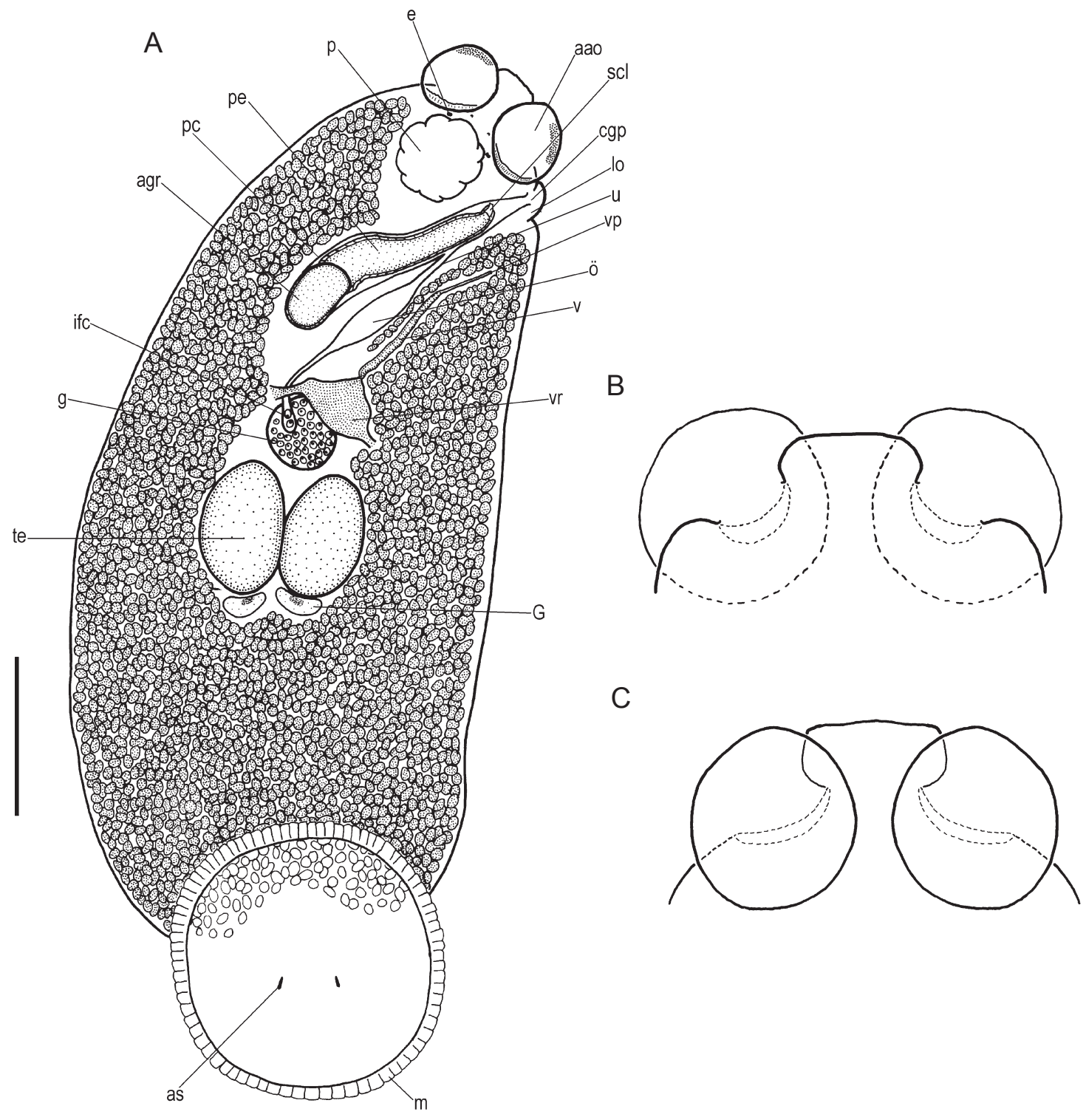

Fig. 1. Dioncopseudobenedenia kala. A - Entire adult animal, ventral view. Composite from paratype MPM No. 15415 and live specimens. Hooklets on haptor not shown (see Fig. 2C). Vitellarium omitted in region beneath marginal valve for clarity; vitellarium at anterior region of haptor shown by transparency to indicate posterior extent of follicles in body proper. B - Diagrammatic representation of anterior attachment organs, dorsal view, not drawn to scale. $\mathbf{C}$ - Diagrammatic representation of anterior attachment organs, ventral view, not drawn to scale. Abbreviations: aao - anterior attachment organ; agr - accessory gland reservoir; as - accessory sclerites; cgp - common genital pore; e - pigmented eye; $\mathrm{G}$ - glands of Goto; g - germarium; ifc - internal fertilisation chamber; lo - lobe; $\mathrm{m}$ - marginal valve; $\ddot{o}$ - oötype; $\mathrm{p}$ - pharynx; $\mathrm{pc}$ - penis canal; pe - penis; scl - sclerite at distal tip of male copulatory organ; te - testis; $\mathrm{u}$ - uterus; $\mathrm{v}$ - vagina; $\mathrm{vp}$ - vaginal pore; $\mathrm{vr}$ - vitelline reservoir. Scale bar $=375 \mu \mathrm{m}$.

(N. garneri Whittington et Kearn, 2009 and N. taiwanensis Whittington et Kearn, 2009, see Whittington and Kearn 2009a) whereas D. kala and the new taxon possess a male copulatory organ that is clearly a muscular penis. Whittington and Kearn (2009a) commented that relatively little evolutionary change may be required to switch from penis to cirrus function or vice versa; this difference in functional morphology can be consistent with closely related taxa.

\section{Dioncopseudobenedenia kala Yamaguti, 1965}

Figs. 1-5, 6A-C, Table 1

Material examined: USNPC No. 63500 (holotype) (1 slide, 1 specimen) ex gills of Naso unicornis (Forsskål), Hawaii; MPM No. 15415 (paratypes) (1 slide, 20 specimens; 19 of $D$. kala, 1 of $D$. macracantha [see below]) ex gills of $N$. unicornis, Hawaii; QM Nos. GL18189, GL18192-3, GL18196 (vouchers) (4 slides, 4 specimens) ex gills and gill chamber of $N$. annulatus (Quoy 
A

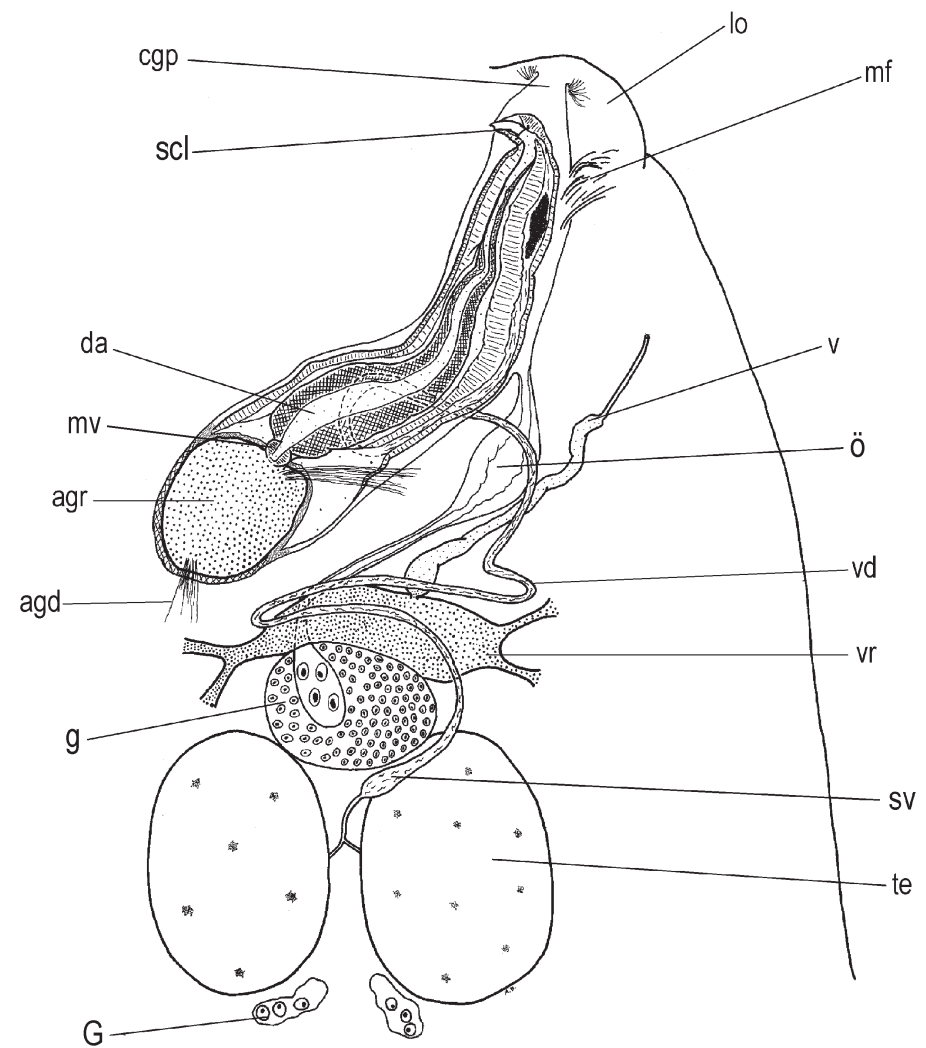

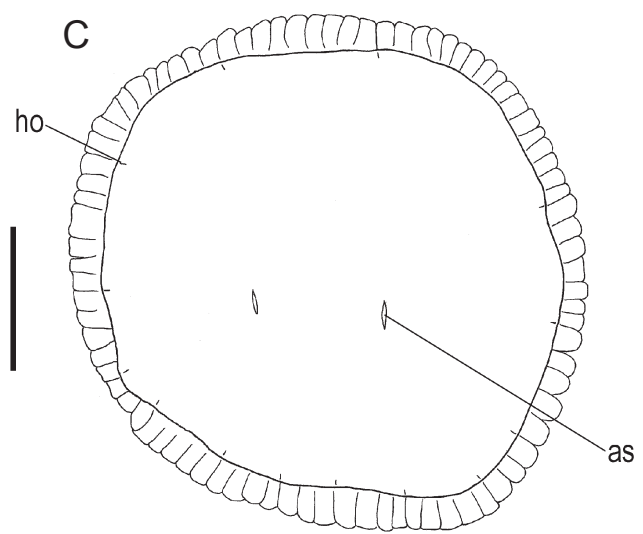

B

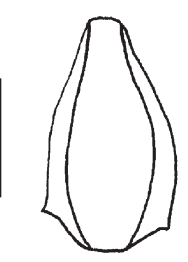

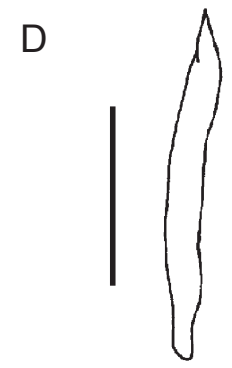

Fig. 2. Dioncopseudobenedenia kala. A - Reproductive system of adult, ventral view. Composite from holotype and live specimens. B - Penis sclerite in side view. Drawn from three live specimens and one sclerite dissected from a preserved specimen and prepared in Hoyer's medium. C - Haptor, ventral view. Composite from QM Nos. GL18189 and GL18193. D - Accessory sclerite drawn from heavily flattened living specimen. Abbreviations: agd - duct from male accessory gland; da - duct of accessory gland reservoir; ho - hooklet; $\mathrm{mf}$ - muscle fibres; $\mathrm{mv}$ - muscular sphincter between accessory gland reservoir and its duct; sv - seminal vesicle; $\mathrm{vd}-$ vas deferens. Other labels as for Fig. 1. Scale bars: $A=325 \mu \mathrm{m} ; \mathrm{B}=50 \mu \mathrm{m} ; \mathrm{C}=300 \mu \mathrm{m} ; \mathrm{D}=35 \mu \mathrm{m}$.

et Gaimard), Heron Island, Queensland, Australia; QM No. GL218123-4 (2 slides, 2 specimens) ex gills and gill chamber of N. lituratus (Forster), Heron Island, Queensland, Australia (present study); MNHN JNC1516B4, B6, B8, B10-B11, B13, B15-B17, B19, B27-32 (16 slides, 16 specimens), SAMAAHC 29920 (6 slides, 6 specimens), MNHN JNC1552A1 (1 slide, 1 specimen, see Perkins et al. 2009), SAMA AHC 29919 (2 slides, 2 specimens) ex gills of $N$. unicornis, Île aux Goélands off Nouméa, New Caledonia (present study). Live specimens from Heron Island, Queensland, Australia (present study).

Redescription. For comparative measurements of material examined, see Table 1. Total length approximately $1.5-3.9 \mathrm{~mm}$. Accessory sclerites 30-80 long, just posterior to haptor centre (Figs. 1A, 2C, D); unclear whether accessory sclerites protrude from ventral haptor surface. One accessory sclerite of each pair small, misshapen in 4 of 19 paratypes. Hamuli absent. Fourteen hooklets at haptor periphery (Fig. 2C). Marginal valve comprising small lobes, of moderately uniform width (Figs. 1A, 2C) with consistent relationship between lobes and hooklets: 3 lobes between each of hooklet pair II on posterior border of haptor; 4 lobes between hooklets of pairs II and III;
5 lobes between hooklets of pairs III and IV; 3 lobes between hooklets of pairs IV and V; 5 lobes between hooklets of pairs V and VI; 6-8 lobes between hooklets of pairs VI and VII; 9-17 lobes between hooklets of pairs VII and VIII (lobe number may differ between specimens but always arranged symmetrically); 9 lobes between hooklets of pair VIII on anterior border of haptor (Fig. 2C).

Anterior attachment organs almost circular (Fig.1A, B, C); attached to body centrally but with free edges; not hooded (see fig. 1B of Whittington et al. 2001). Lens remnants associated with pigmented eyes in all specimens, but often some distance from pigment cups. Type material and new Australian and New Caledonian specimens confirm presence of tiny, laterally directed papillae on body margin (papillae not drawn in figures due to scale). Absence of papillae due to specimen orientation in some individuals confirms marginal location.

Muscular sphincter between accessory gland reservoir and its duct. Vas deferens within penis muscular (Fig. 2A). Ducts entering male accessory gland reservoir in two regions: posteriorly and anterolaterally (Fig. 2A). Distal tip of penis bears short, gutter-shaped sclerotised structure (Figs.1A, 2A, B). Conspicuous lobe dorsal to common 


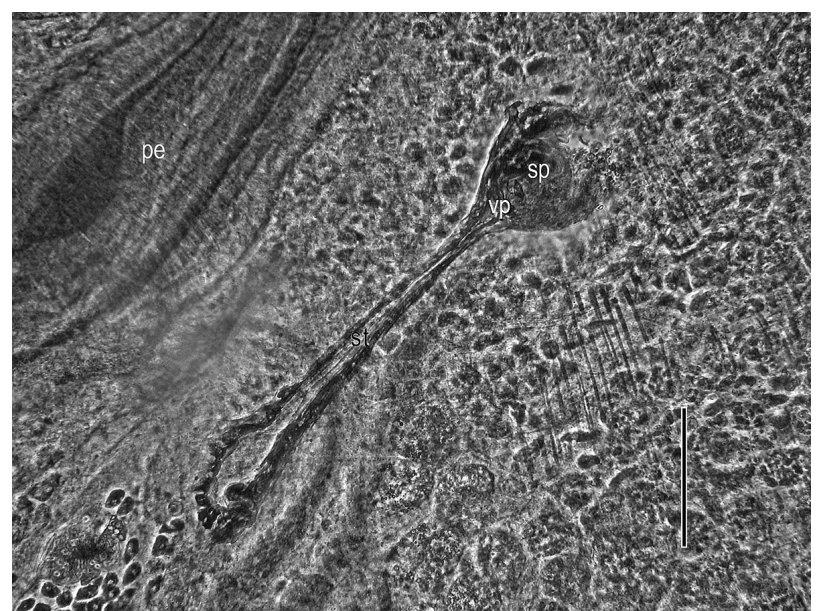

Fig. 3. Dioncopseudobenedenia kala. Spermatophore (sp) adjacent to dorsal vaginal pore (specimen on slide labelled JNC1516B5 in SAMA AHC 29920). Abbreviations: pe - penis; st - stalk of spermatophore; vp - vaginal pore. Phase contrast microscopy. Scale bar $=50 \mu \mathrm{m}$.

genital pore (Figs. 1, 2A). Vagina narrow distally, widening proximally about one-third along length; wider, proximal section with muscular walls, often dilated, spermfilled, vaginal pore dorsal (Fig. 2A). In two specimens of D. kala from N. unicornis off New Caledonia (SAMA AHC 29919 labelled as JNC1552A8, SAMA AHC 29920 labelled as JNC1516B5), stained structure on dorsal surface in region of vaginal opening interpreted as spermatophore (Fig. 3).

Observations on eggs. Adult $D$. kala laid few tetrahedral eggs with sides 75-90 $\mu \mathrm{m}(\mathrm{n}=3)$ long and a filament 180-215 $\mu \mathrm{m}(\mathrm{n}=3)$ long, after removal from their host. A dish containing 5 adult parasites in FSW at $23^{\circ} \mathrm{C}$ for $12 \mathrm{~h}$ contained $<30$ eggs. At $23-27^{\circ} \mathrm{C}$, these eggs hatched after 7-12 days.

Description of oncomiracidium (Fig. 4). Based on 5 specimens; 3 measured. Oncomiracidium $\sim 200 \mu \mathrm{m}$ long. Accessory sclerites 9-19 (15) long. Anterior and posterior hamuli present, resembling tiny straight 'pegs'; length differing considerably between specimens: anterior hamuli, 2, 11; 1, 8; 2, 13; posterior hamuli, 2, 3; 2, 4; 5, 2. Structures that may be glands of Goto (Fig. 4) larger than those reported in larvae of Benedenia lutjani Whittington et Kearn, 1993 (see Whittington and Kearn 1993) and B. rohdei Whittington, Kearn et Beverley-Burton, 1994 (see Whittington et al. 1994). Flame bulbs and arrangement of protonephridial ducts not determined with certainty because these structures were difficult to see without phase contrast optics, which were unavailable when larvae were studied. Position of 8 flame bulbs shown in Fig. 4.

Observations on live adult specimens. Live $D$. kala attached to glass vessels made similar movements to B. rohdei (as Benedenia sp. 1) (Kearn and Whittington

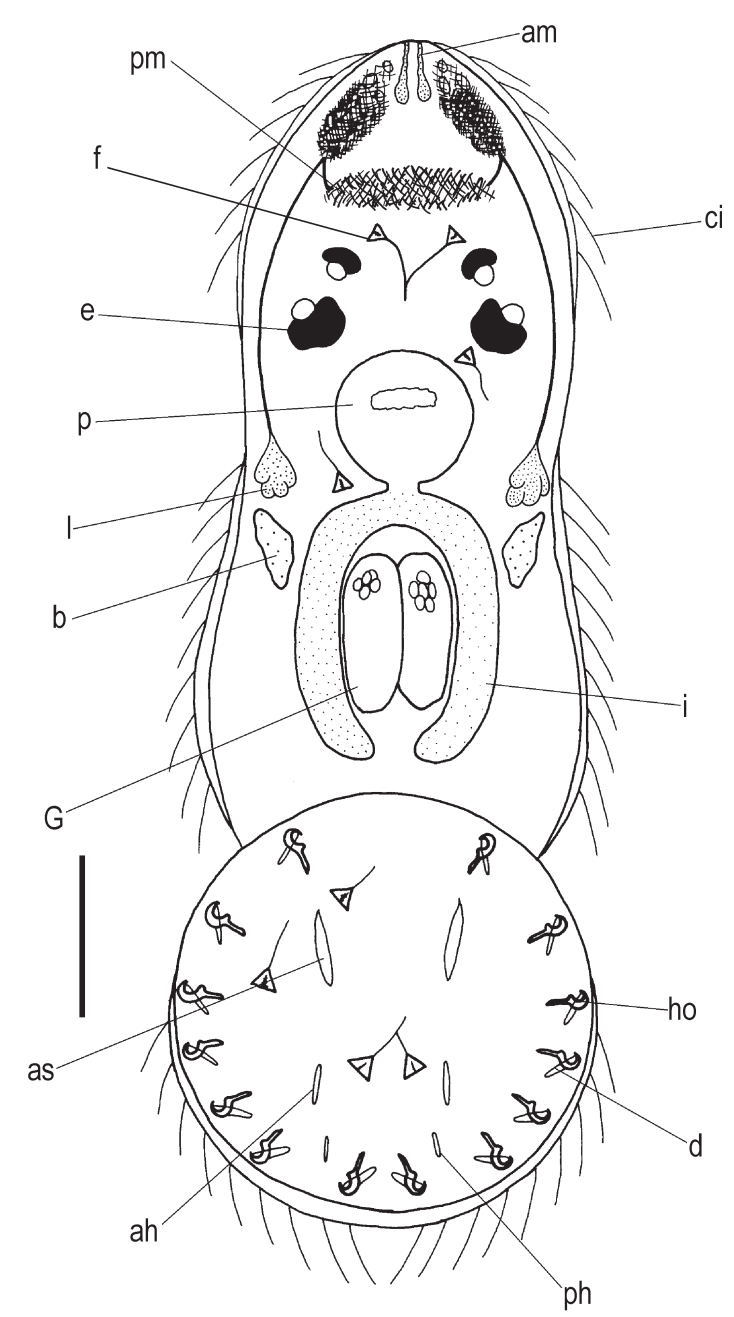

Fig. 4. Anatomy of the oncomiracidium of Dioncopseudobenedenia kala hatched from eggs collected from adult specimens from Heron Island. Entire animal, ventral view. Abbreviations: ah - anterior hamulus; am - anterior median gland; b-excretory bladder; ci-cilia; d-domus; f-flame bulb; $\mathrm{i}$ - intestine; 1 - lateral gland cells containing granular secretion; $\mathrm{ph}$ - posterior hamulus; $\mathrm{pm}$ - gland cell containing needle-like secretion. Other labels as for Figs. 1 and 2. Scale bar $=35 \mu \mathrm{m}$.

1992) and mating was observed twice between 2 different pairs of D. kala. Parasites approached each other anterior end to anterior end (Fig. 5B), making frequent contact. Lateral contact between individuals resulted in parasites protruding the penis through the common genital pore and curling the edge of the body near the common genital pore dorsally (Fig. 5A). These movements resulted in two worms each protruding their penis tip in the region adjacent to the dorsal vaginal opening of the other individual (Fig. 5B). The process lasted 2-4 s. When the pairs had separated the vagina of one worm contained a large bolus of material without a boundary layer, similar to that observed in some fixed specimens, but no material was found in the vagina of the other specimen. There were some active spermatozoa in this material, but the bolus 
A

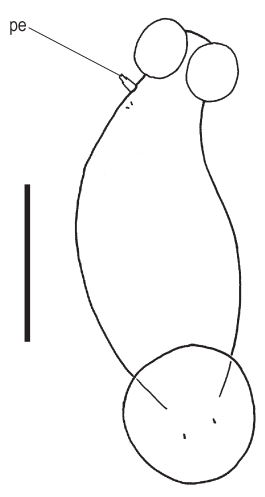

B

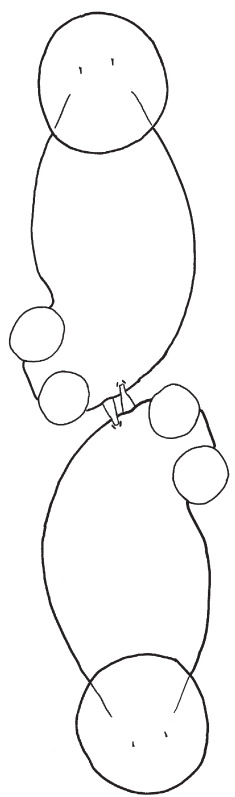

Fig. 5. Mating behaviour in Dioncopseudobenedenia kala observed in specimens from Heron Island. A - Dorsal view of premating posture showing extension and curving of anterior part of body and protrusion of penis (pe). B - Dorsal view of two adjacent parasites each with the penis protruded and close to dorsal vaginal pore of partner. Scale bar $=1 \mathrm{~mm}$.
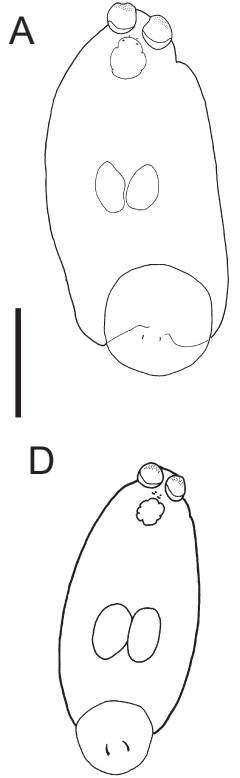

B

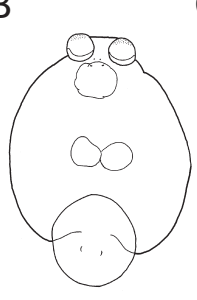

C

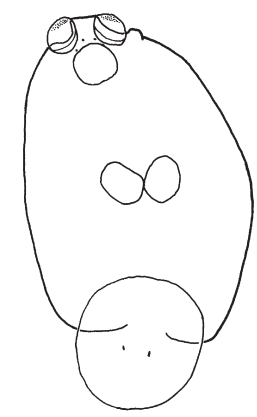

$\mathrm{E}$

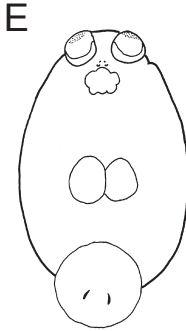

$\mathrm{F}$

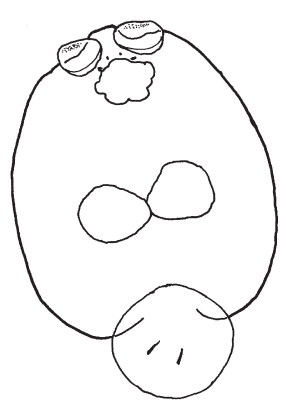

Fig. 6. Body profiles of Dioncopseudobenedenia kala (A-C) and D. macracantha (D-F). Specimens of D. kala from (A) Hawaii (based on holotype USNPC No. 63500), (B) Heron Island (based on QM No. GL 18192) and (C) New Caledonia (based on MNHN JNC1516B4). Specimens of D. macracantha from (D) Hawaii (based on holotype USNPC No. 63594), (E) Heron Island (based on QM No. GL18191) and (F) New Caledonia (based on MNHN JNC1516B1). Note that at Heron Island (B, E), both species have a short, relatively broad body. Scale bar $=1 \mathrm{~mm}$.

was not as dense as the putative spermatophores observed by us or those described by Kearn (1970) for Entobdella soleae (van Beneden et Hesse, 1864) Johnston, 1929. It is unclear if mutual copulation by intromission occurred although there is a large discrepancy between penis size and distal width of the vagina (e.g. Fig. 2A) or whether it represented spermatophore exchange (e.g. Fig. 3). Fig. 3 shows the spermatophore partly in the vagina but with much of its mass external to the worm.

We observed another live worm insert its penis into its own oötype.

Type host: Naso unicornis (Forsskål) (Acanthuridae, Perciformes).

Site on host: Gills, including primary lamellae (by folding haptor transversely or longitudinally around individual primary lamella), gill arch and inside of operculum.

Type locality: Hawaii.

In fection details: At Heron Island (present study based on 2 host species): prevalence $22 \%$ ( $\mathrm{n}=18 \mathrm{fish}$ ); intensity 1-3 (3) (calculated from $n=4$ infected fish dissected within $6 \mathrm{~h}$ of capture); off Nouméa (present study), prevalence $100 \%$ ( $\mathrm{n}=2$ fish; intensity 23,30 ).

Published records: Perciformes: Acanthuridae: N. unicornis (see Yamaguti 1965); N. annulatus (see Young 1970); $N$. lituratus (present study).

Descriptions: Yamaguti $(1965,1968)$.

Geographic distribution: Hawaii (Yamaguti 1965, 1968); Heron Island, Queensland, Australia (Young 1970; present study); Nouméa, New Caledonia (present study).

Specimens deposited: Vouchers QM No. GL2181234 (2 slides, 2 specimens) ex gills of $N$. lituratus (Forster), Heron Island, Queensland, Australia (present study); vouchers MNHN JNC1516B4, B6, B8, B10-B11, B13, B15-B17, B19, B27-32 (16 slides, 16 specimens), SAMA AHC 29920 (6 slides, 6 specimens), MNHN JNC1552A1 (1 slide, 1 specimen), SAMA AHC 29919 (2 slides, 2 specimens) ex gills of N. unicornis, Île aux Goélands off Nouméa, New Caledonia.

Remarks. Yamaguti (1965) described and Yamaguti (1968) redescribed D. kala. We base our comparison on Yamaguti (1965). We compared it with material from Heron Island, lodged in QM. Of these specimens we regard GL18189, GL18192-3 and GL18196 as D. kala. There is some variation in the shape of the body between the Hawaiian specimens of Yamaguti (1965), material from Heron Island and from New Caledonia (Fig. 6A, B, C, respectively), but we regard all as conspecific. Our studies of live $D$. kala indicate that variation in body shape is not due to processing. Variation in the shape of the anterior attachment organs appears largely due to handling. Specimens we collected from Heron Island are almost identical morphometrically to those collected by Young from the same locality (Table 1).

Yamaguti (1965) did not describe the short, guttershaped sclerotised structure at the distal tip of the penis that may reinforce the terminal ejaculatory duct (Fig. 2A, B). 
Yamaguti (1965; his figure 1A) represented ambiguously a lobe dorsal to the common genital pore (Figs. 1A, 2A). Lobes are common near the genital pores in benedeniines (Whittington and Kearn 1993, Ogawa et al. 1995a, Whittington et al. 2001, Deveney and Whittington 2010, Whittington and Deveney in press). Yamaguti (1965) depicted the vagina as a simple tube with a slight proximal swelling, but the vagina is narrow distally, widens dramatically about one-third along its length and the dilated, wider proximal section, which often contains sperm, has muscular walls (Fig. 2A).

Mating behaviours in benedeniines are diverse. Dioncopseudobenedenia kala can insert its penis into its own oötype as can Benedeniella macrocolpa (Lühe, 1906) Johnston, 1929 (see Kearn and Whittington 1992), Neobenedenia melleni (MacCallum, 1927) Yamaguti, 1963 (see Whittington and Horton 1996) and several species of Neoentobdella (see Kearn and Whittington 2005, Whittington and Kearn 2009a, b). Although Kearn et al. (1993) showed that isolated E. soleae were infertile, other benedeniines may self-inseminate (Kearn and Whittington 1992, Whittington and Horton 1996, Kearn and Whittington 2005, Whittington and Kearn 2009a, b, present study). At Heron Island, Dioncopseudobenedenia infections occur at low intensity (1-3 specimens) and self-insemination may be important for parasites that live in relative isolation. Putative external spermatophores (SAMA AHC 29919 labelled as JNC1552A8, SAMA AHC 29920 labelled as JNC1516B5; Fig. 3), observations of possible intromission (Fig. 5B) and penis insertion via the oötype suggest that $D$. kala possesses diverse insemination strategies. This is the first report of spermatophore production by a capsalid from the gills of a host (Kearn and Whittington 1992, Kearn et al. 2006).

Dioncopseudobenedenia kala can be distinguished from $D$. macracantha by possessing a sclerite at the terminal tip of the penis and its much smaller accessory sclerites. It can be differentiated from the new species (see below) by its membranous marginal valve without muscular loculi and differences in the shape of the sclerite associated with the penis.

\section{Dioncopseudobenedenia macracantha Yamaguti, 1968 Figs. 6D-F, 7, 8, Table 1}

Material examined: USNPC No. 63594 (holotype and paratypes) (1 slide, 7 specimens) ex gills of Naso unicornis, Hawaii; HWML No. 1402 (voucher) (1 slide, 1 specimen) ex gills of $N$. annulatus, Heron Island, Queensland, Australia; MPM No. 15415 (labelled as paratypes) (1 slide, 20 specimens; 19 D. kala, 1 D. macracantha) ex gills of $N$. unicornis, Hawaii; QM Nos. GL18191, GL18194-5 (3 slides, 3 specimens) ex gills of $N$. annulatus, Heron Island, Queensland, Australia; GL218122 (1 slide, 1 specimen) ex gills of $N$. brevirostris
(Cuvier), Heron Island, Queensland, Australia; MNHN JNC1516B1 (1 slide, 1 specimen) ex gills of $N$. unicornis, Île aux Goélands, off Nouméa, New Caledonia.

Observations. Yamaguti often used the term cirrus for the male copulatory organ in capsalids. He described the eversible male copulatory organ of Metabenedeniella hoplognathi (Yamaguti, 1942) Yamaguti, 1958 as a cirrus but also termed the male copulatory organ of D. macracantha a cirrus (Yamaguti 1968). The penis of this species is often preserved at different states of extension. The wall of the penis canal of $D$. macracantha lacks strong musculature, but the organ itself is muscular (Fig. 8A, B). The duct of the accessory gland reservoir is muscular and two bands of circular muscle span the proximal part of the male copulatory organ (Fig. 8B).

Yamaguti (1968) illustrated ducts running from each gland of Goto to the testes in his figure 13A, but he did not discuss these and we failed to find them. Yamaguti described the common genital pore as opening on the lobe immediately posterior and slightly lateral to the left anterior attachment organ. Our observations indicate that the common genital pore opens slightly submarginally and ventrally, and that the lobe lies dorsal to, and extends laterally over, the pore and body margin (Figs. 7, $8 \mathrm{~A}$ ). The vagina is a conspicuous duct proximally, with a prominent narrowing and a widened muscular wall at its distal third with a dorsal pore (Figs. 7, 8A). Most adult specimens have sperm in the proximal part of the vagina.

Yamaguti (1968) depicted the large accessory sclerites with a recurved distal end (see Yamaguti 1968 fig. 1A), but we observed only a tiny distal hook (Fig. 8D). The accessory sclerites protrude from the ventral haptor surface; they appear to be functional, but are not associated with tendons or musculature despite their prominent proximal notch (Fig. 8D). We noted prominent wavy muscles near the haptor periphery (Fig. 7). The single specimen from Nouméa, New Caledonia conforms to the description above (see Table 1 for morphometric comparisons).

Yamaguti (1968) did not discuss the arrangement of lobes or the morphology of the marginal valve. The relationship between marginal valve and hooklets is: 3 lobes between hooklets of pair II on posterior border of haptor; 3-4 lobes between hooklets of pairs II and III and between hooklets of pairs III and IV; 3 lobes between hooklets of pairs IV and V; 6 lobes between hooklets of pairs V and VI; 7 lobes between hooklets of pairs VI and VII; 9 lobes between hooklets of pairs VII and VIII and between each hooklet of pair VIII on anterior border of haptor (Fig. 8C).

Type host: Naso unicornis (Forsskål) (Acanthuridae, Perciformes).

Site on host: Gills (Yamaguti 1968); by folding haptor transversely or longitudinally around individual primary gill lamellae (present study). 


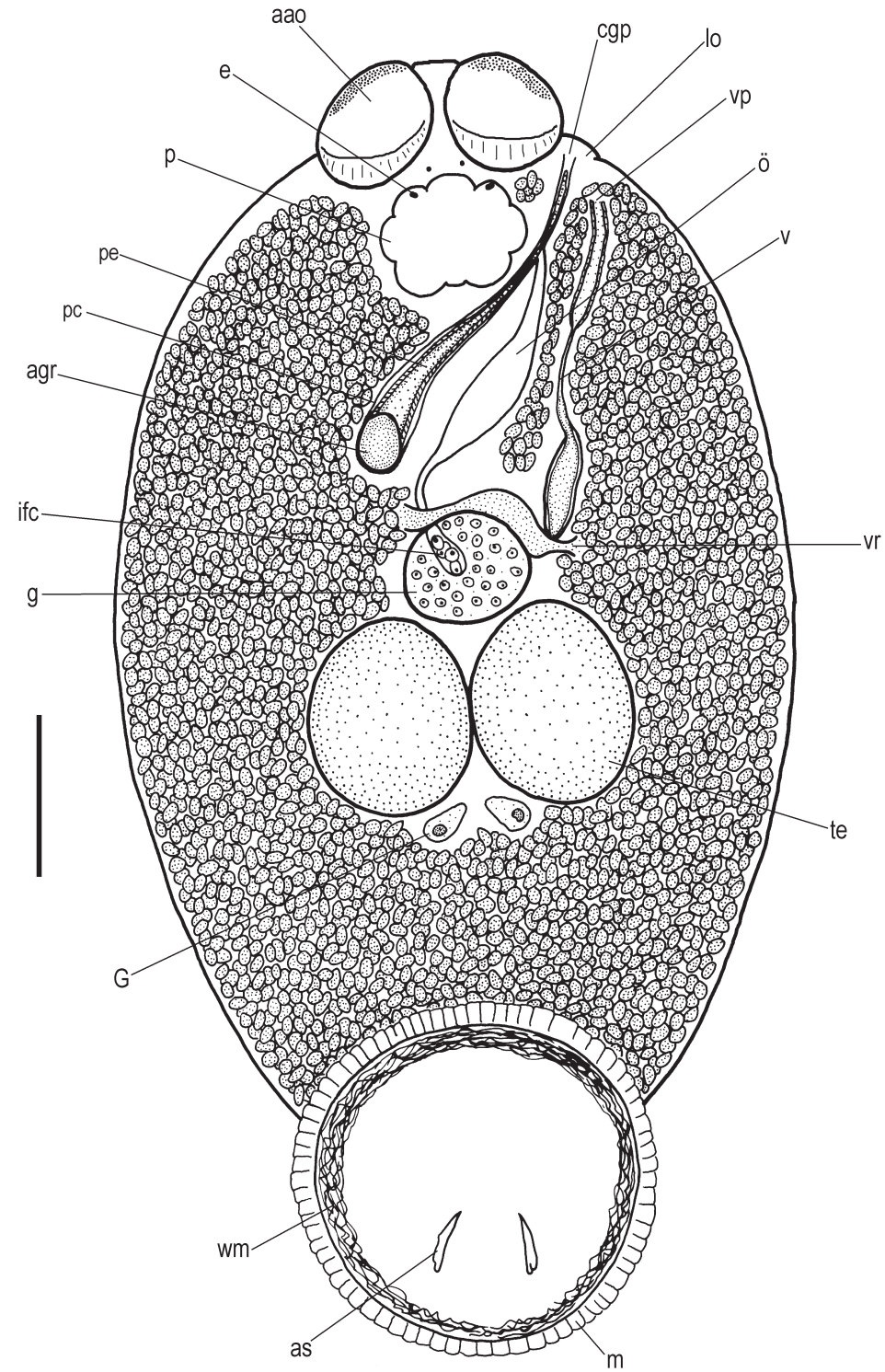

Fig. 7. Dioncopseudobenedenia macracantha. Entire adult animal, ventral view. Composite drawing from all available material. Vitellarium omitted in region beneath haptor and marginal valve for clarity. Abbreviations: wm - wavy muscle. Other labels as for Figs. 1 and 2. Scale bar $=300 \mu \mathrm{m}$.
Type locality: Hawaii.

In fection details: At Heron Island (present study): prevalence $8 \%(\mathrm{n}=12$ fish); intensity 2 (calculated from $\mathrm{n}=1$ infected fish dissected within 6 h of capture); off Nouméa (present study): prevalence $50 \%$ ( $\mathrm{n}=2 \mathrm{fish}$; intensity 1 (calculated from $n=1$ infected fish).

Published records: Perciformes: Acanthuridae: N. unicornis (see Yamaguti 1968); N. annulatus (see Young 1970); N. brevirostris (present study).

Description: Yamaguti (1968).

Geographic distribution: Hawaii (Yamaguti 1968); Heron Island, Queensland, Australia (Young 1970; present study); Nouméa, New Caledonia (present study).

Designation of types: Holotype and paratypes as designated by Yamaguti (1968) for D. macracantha (see "Material examined" section above).

Remarks. Yamaguti (1968) described D. macracantha from 9 specimens, 8 of which we have examined. One worm mounted with 19 specimens of D. kala in MPM may not have been used in the original description. Of the specimens from $N$. annulatus from Heron Island deposited by Young, 4 are D. macracantha (QM Nos. GL18191, GL18194-5; HWML No. 1402). The specimens from Heron Island are smaller and proportionally broader than those from Hawaii. The specimens from New Caledonia are larger than the other material (Fig. 6D-F) but we regard them as conspecific.

The penis of $D$. macracantha is unusual and its structure and function were difficult to interpret. It is more muscular than the cirrus of species of Trimusculotrema Whittington et Barton, 1990 (see Whittington and Barton 1990) and Benedeniella Johnston, 1929 (see Kearn and Whittington 1992, Whittington 2010) and much shorter than the cirrus of species of Metabenedeniella (see Horton and Whittington 1994). It resembles the male copulatory organ of Neoentobdella garneri (see Whittington 

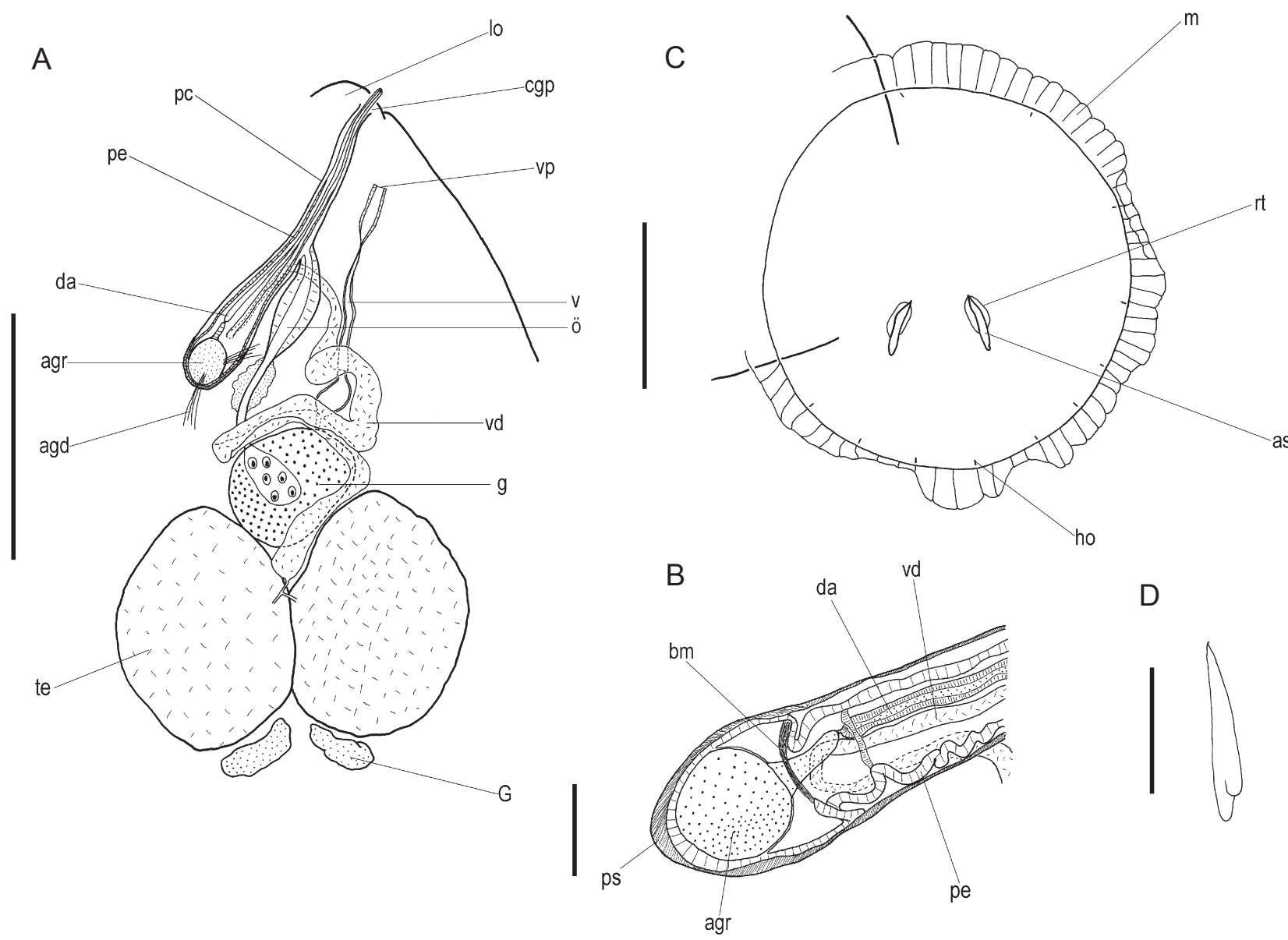

Fig. 8. Dioncopseudobenedenia macracantha. Each drawing is a composite from all available material. A - Reproductive system of adult, ventral view. Vitelline reservoir omitted for clarity. B - Proximal end of penis. C - Haptor. Peripheral wavy muscles omitted to show location of hooklets with respect to marginal valve. D - Accessory sclerite. Abbreviations: bm - band of muscle; ps - penis sac; $\mathrm{rt}$ - ridge of tissue. Other labels as for Figs. 1 and 2. Scale bars: $\mathrm{A}=350 \mu \mathrm{m} ; \mathrm{B}=50 \mu \mathrm{m} ; \mathrm{C}=250 \mu \mathrm{m} ; \mathrm{D}=70 \mu \mathrm{m}$.

and Kearn 2009a, their figure 2), but has less musculature in the canal wall and includes more musculature than the male copulatory organ of $N$. garneri. The penis of D. macracantha has some musculature at the proximal end of the penis surrounding the accessory gland reservoir (Fig. 8B), and some muscle fibres in the penis (Fig. $8 \mathrm{~A}$ ), but it is less muscular than that of D. kala and the new taxon described below. The walls of the penis have no apparent muscle fibres (Fig. 8B).

One large specimen deposited by Young in the QM (GL18190) poses an interesting taxonomic conundrum because its male copulatory organ is clearly that of D. macracantha, but the accessory sclerites are small (36 and 45 long; Table 1).

\section{Dioncopseudobenedenia ancoralis $\mathrm{sp} . \mathrm{n}$.}

Figs. 9-11, Table 1

Material examined: QM Nos. GL18179-18182, GL18184-18188 (9 slides, 9 specimens) and GL18183 (1 slide, 1 mounted haptor) ex gills of Siganus lineatus
(Valenciennes) from Green Island; GL218121 (1 slide, 1 specimen) ex gills of $S$. lineatus from Heron Island; MNHN JNC1366B1 (1 slide, 1 specimen), SAMA AHC 29921 (1 slide, 1 specimen $=$ JNC1366B2) ex gills of S. lineatus off Îlot Canard, Nouméa City, New Caledonia.

Description. Dioncopseudobenedenia as amended above. (Based on studies of 2 live specimens from Heron Island [1 of which was later prepared for SEM] and 13 whole-mounts $[9$ complete specimens plus 1 mounted haptor from Green Island; 1 complete specimen from Heron Island; 2 complete specimens from Nouméa, New Caledonia]). Measurements presented below are of material from Green Island. See Table 1 for morphometric comparisons with single mounted specimen from Heron Island and two mounted specimens from Nouméa. Total length including haptor 1.14-2.02 (1.79) $\mathrm{mm}$; maximum width $0.57-1.38(1.15) \mathrm{mm}$ at level of testes (Fig. 9A). Haptor almost circular 241-420 (365) × 227-419 (351). Periphery of haptor proper distinctly muscular, loculate (Figs. 9A, 11). Accessory sclerites well posterior on haptor, 20-31 (26) long, broad, tapering distally, with small 


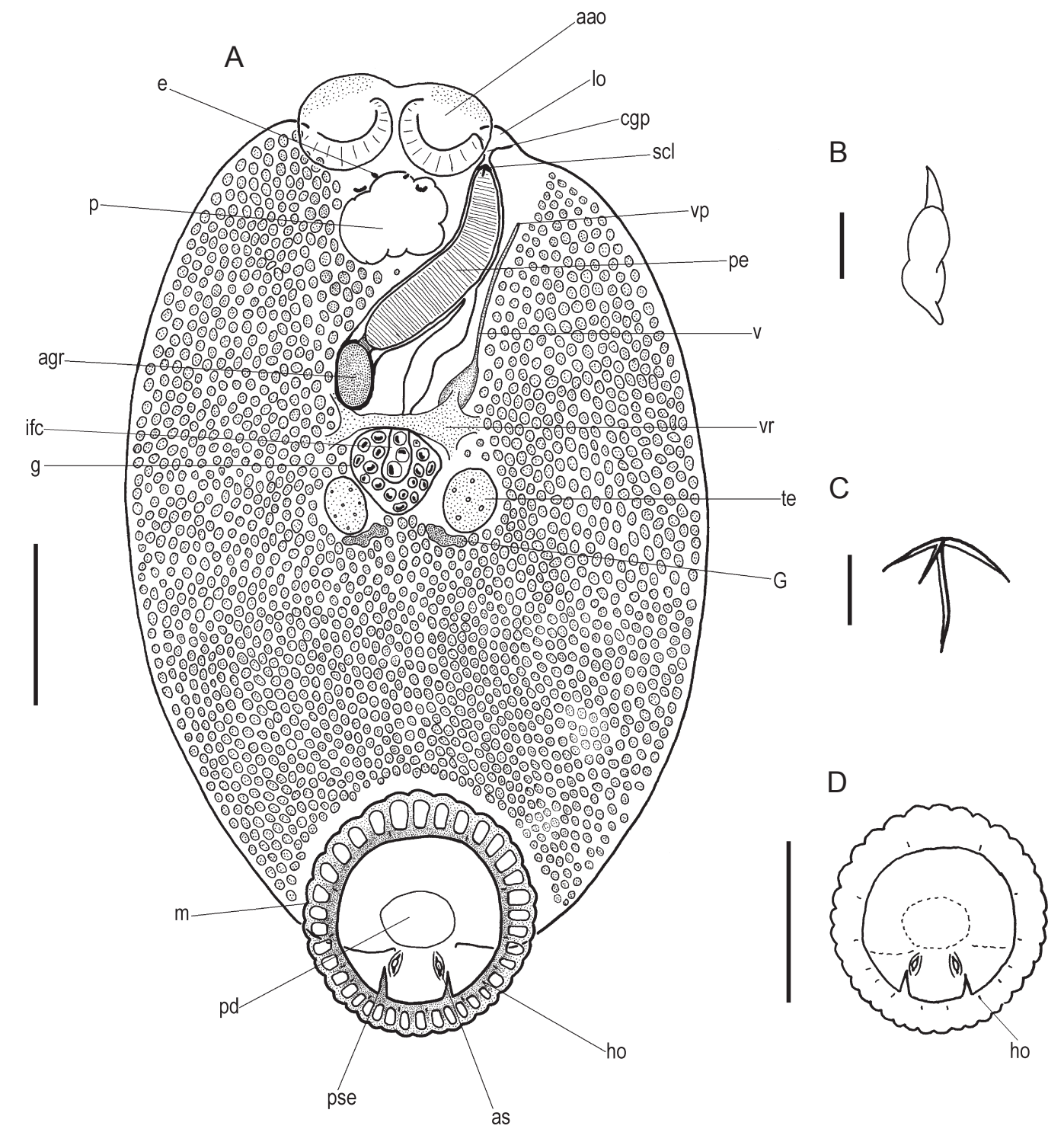

Fig. 9. Dioncopseudobenedenia ancoralis sp. n. A - Entire adult animal, ventral view. Composite from live specimens and all available mounted material. B - Accessory sclerite from specimen prepared in Hoyer's medium. C - Penis sclerite dissected from a preserved specimen and prepared in Hoyer's medium. D - Outline of haptor showing hooklet positions. Abbreviations: pd - depression at peduncle where body proper joins haptor; pse - pseudoseptum. Other labels as for Figs. 1 and 2. Scale bars: $\mathrm{A}=300 \mu \mathrm{m} ; \mathrm{B}=10$ $\mu \mathrm{m} ; \mathrm{C}=20 \mu \mathrm{m} ; \mathrm{D}=300 \mu \mathrm{m}$.

notch proximally; no associated tendon (Fig. 9A); enveloped in ridge of (muscular?) tissue (Figs. 9A, D, 11). One accessory sclerite missing in 3 of 11 specimens from Australia. Accessory sclerites not protruding from ventral haptor surface (Fig. 11). Two pseudosepta extend anteriorly from posterior edge of haptor (Figs. 9A, D, 11). Fourteen hooklets 8-11.5 (10) long distributed as illustrated (Fig. 9D). Haptor margin approximately 50-60 wide, scalloped at edges, thickened (muscular?) not membranous, loculate, each loculus modified forming cup-like (sucking?) structure (Fig. 11). Arrangement of peripheral loculi and hooklets reasonably consistent: 2 lobes between each hooklet of pair II on posterior border of haptor; 3 lobes between hooklets of pairs II and III; 2 lobes between hooklets of pairs III and IV; 1 lobe between hooklets of pairs IV and V; 2 lobes between hooklets of pairs $\mathrm{V}$ and VI; 3 lobes between hooklets of pairs VI and VII; 4 lobes between hooklets of pairs VII and VIII; and 4-6 lobes between each hooklet of pair VIII on anterior border of haptor (Fig. 9A, D).

Anterior attachment organs almost circular, 130-225 (191) in diameter; anterior part glandular, posterior part a muscular (sucking?) region (Fig. 9A). Body proper extends anteriorly nearly to anteriormost margin of anterior attachment organs (Fig. 9A). Two pairs of eyes with lens remnants in all specimens. Pharynx 85-193 (157) × 136273 (219). Gut dendritic; unclear whether caeca confluent or not posteriorly. 


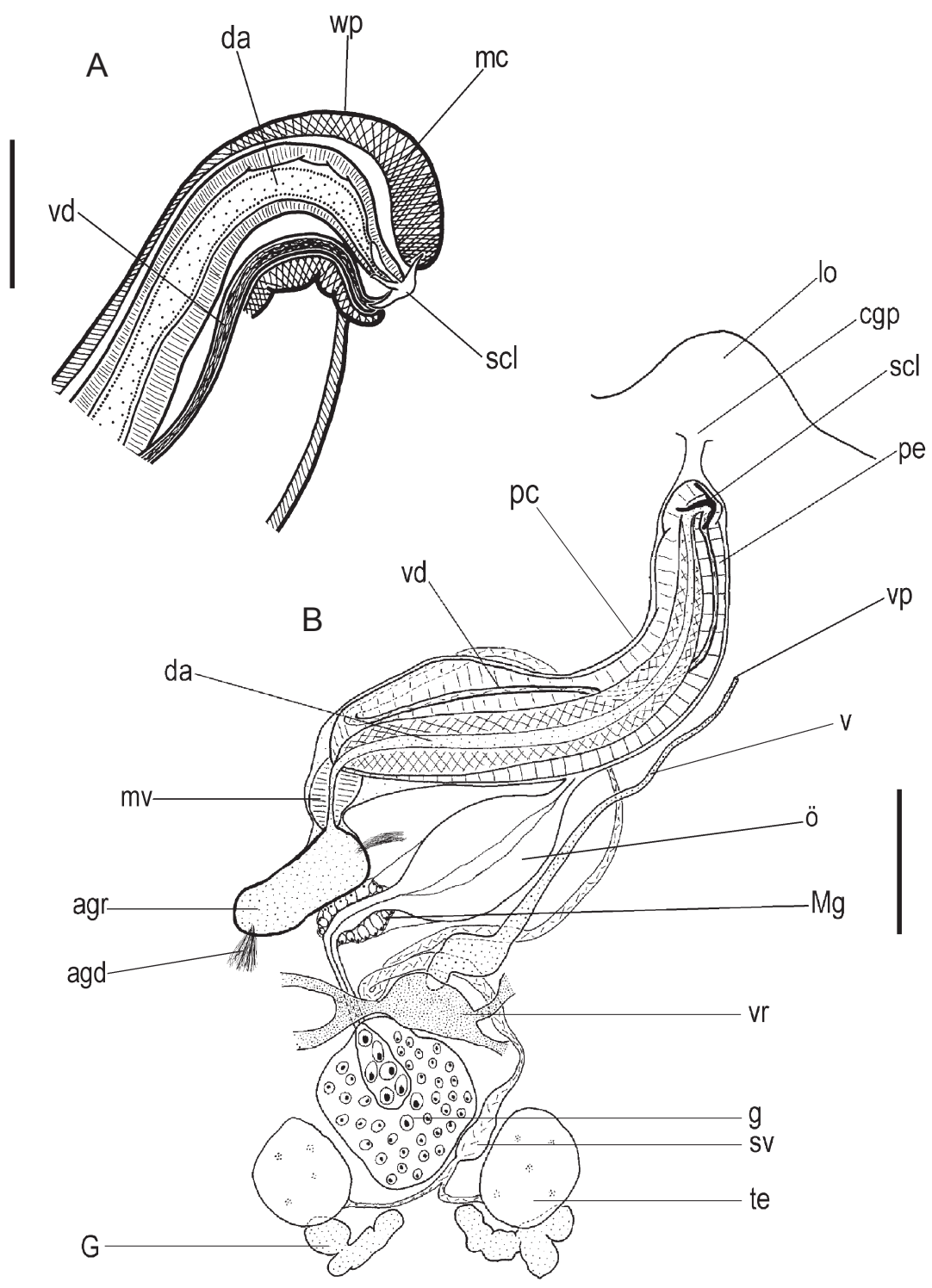

Fig. 10. Dioncopseudobenedenia ancoralis sp. $n$. A - Distal tip of penis showing terminal sclerite (scl). Penis canal omitted. B - Reproductive organs, ventral view. Composite from two live specimens. Abbreviations: mc - muscles of penis; Mg - Mehlis' glands; wp - wall of penis. Other labels as for Figs. 1 and 2. Scale bars: $A=50 \mu \mathrm{m} ; \mathrm{B}=150 \mu \mathrm{m}$.

Glands of Goto present; large, of irregular shape. Testes two, small 73-145 (116) × 48-126 (91). Vas deferens swells to form seminal vesicle at level of germarium (Fig. 10B). Penis muscular lying inside penis canal with narrow walls (Fig. 10B). Vas deferens enters penis canal dorsally, winds to tip of penis; joins duct of accessory gland reservoir near distal tip of penis (Fig. 10A, B). Intrapenile lengths of accessory gland reservoir duct and vas deferens with distinct musculature. Distal end of penis with sclerotised element similar to anchor or grappling hook (Figs. 9C, 10A, B). Tissue folds at distal penis tip with terminal sclerite (Fig. 10A). Wall of accessory gland reservoir merges with wall of penis canal; receives two bundles of ducts from accessory glands, one bundle proximally, one distally (Fig. 10B). Uterus short, joining penis canal mid-way along its length. Germarium round, with internal (fertilisation?) chamber containing larger oocytes. Vitellarium extensive; extending from anterior margin on right side of body posteriorly to anterior margin of haptor; absent from region between pharynx and anterior attachment organs and absent from region of left anterior body near penis canal and common genital pore (Fig. 9A). Vitelline reservoir irregularly elongate. Common genital pore ventral, submarginal, covered dorsally by rounded lobe, just posterior to left anterior attachment organ. Penis protrusible via common genital pore. Proximal end of vagina expands into spacious chamber. Distal part of vagina a narrow, simple tube. Vaginal pore dorsal, posterior to penis canal at level of posterior region of pharynx (Figs. 9A, 10B). Pore without muscular adornments or lobes. Eggs tetrahedral with short slender plain appendage from one non-opercular pole. 
Ty pe host: Siganus lineatus (Valenciennes) (Siganidae, Perciformes).

Site on host: Gills, including primary gill lamellae, gill arches, gill rakers and inside of operculum.

Type locality: Green Island, Queensland, Australia $\left(16^{\circ} 46^{\prime} 00^{\prime \prime} \mathrm{S}, 145^{\circ} 59^{\prime} 00^{\prime \prime} \mathrm{E}\right)$ (material collected by Dr. P. Young, collection date unknown).

Infection details: At Heron Island: prevalence $8 \%(\mathrm{n}=$ 25 fish); intensity 1 (calculated from $n=2$ infected fish dissected within $6 \mathrm{~h}$ of capture); off Nouméa: prevalence $100 \%$ ( $\mathrm{n}=1$ fish); intensity 4 .

Geographic distribution: Green Island and Heron Island, Queensland, Australia; off Nouméa, New Caledonia.

Ety mology: The specific epithet ancoralis is derived from the Greek "of an anchor" and refers to the anchor-shaped sclerite at the distal tip of the penis.

Designation of types: Holotype QM GL18180, 9 paratypes QM GL18179, GL18181-18188 (all material ex gills of Siganus lineatus (Valenciennes) collected by Dr. P. C. Young from Green Island). Voucher QM GL218121 (1 slide, 1 specimen) ex gills of $S$. lineatus from Heron Island (present study); MNHN JNC1366B1 (1 slide, 1 specimen), SAMA AHC 29921 ( 1 slide, 1 specimen $=$ JNC1366B2) ex gills of $S$. lineatus, Îlot Canard, off Nouméa, New Caledonia (present study).

Remarks. Dioncopseudobenedenia ancoralis bears a sclerite shaped like an anchor on its penis (Fig. 9C); the terminal penis sclerite in D. kala is gutter-shaped (Fig. 2B) and a sclerite is absent in D. macracantha. The haptor of $D$. ancoralis has a periphery that resembles Pseudallobenedenia apharei Yamaguti, 1966 (see Yamaguti 1966) or the peripheral loculi in merizocotyline (Monocotylidae) monogeneans (Chisholm and Whittington 1999). The accessory sclerites of $D$. ancoralis do not protrude from the ventral surface of the haptor (Fig. 11). A slight circular depression at the centre of the ventral haptor surface is not a central "loculus", but is associated with musculature of the peduncle joining the body proper of the worm to the haptor. The ridges of tissue associated with the accessory sclerites are similar to those of Benedenia sciaenae (van Beneden, 1856) Odhner, 1905 (see Whittington et al. 2001) rather than true septa of capsaline or trochopodine monogeneans. The pseudosepta of D. ancoralis (Figs. 9A, D, 11) are like those observed in Troglocephalus Young, 1967 (Monocotylidae) (see Young 1967) and in Heliocotyle Neifar, Euzet et Ben Hassine, 1999 (Monocotylidae) (see Neifar et al. 1999, Chisholm and Whittington 2000) but the haptor of $D$. ancoralis bears only a single pair of pseudosepta and they do not lie within loculi.

Adult specimens of $D$. ancoralis have small testes and large glands of Goto. These organs may change size during development. Protandry has been reported in many capsalids (Kearn 1963, Kearn et al. 1992, Whittington and Kearn 1993) but it seems more likely that sexually mature specimens may undergo testicular atrophy as observed in Benedenia fieldsi Deveney et Whittington, 2010 and pos-

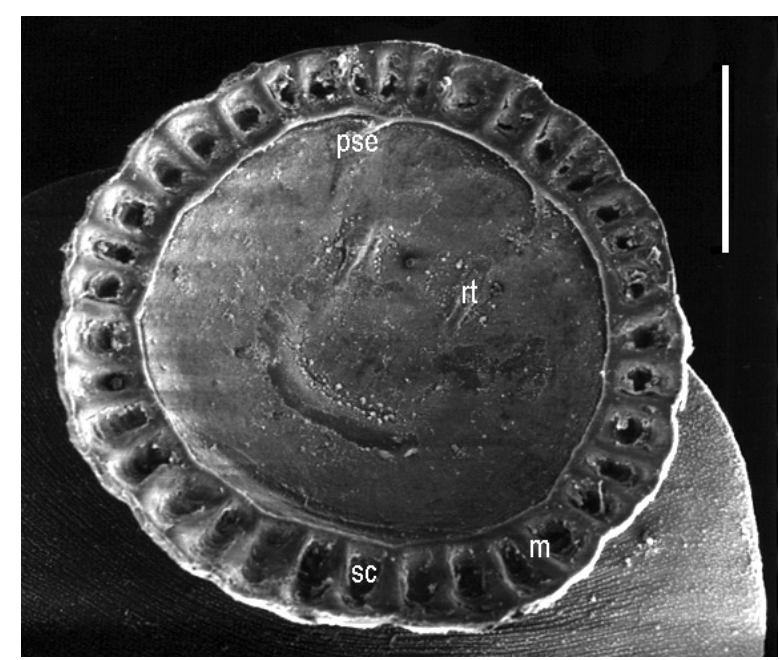

Fig. 11. Dioncopseudobenedenia ancoralis sp. n. Scanning electron micrograph of ventral surface of haptor. Note that accessory sclerites do not protrude from haptor and each individual lobe of marginal valve ( $\mathrm{m}$ ) forms a cup-like (sucking?) structure (sc). Other labels as for Figs. 8 and 9. Scale bar $=100 \mu \mathrm{m}$.

sibly in Benedenia disciliata Whittington et Deveney in press (Deveney and Whittington 2010, Whittington and Deveney in press, respectively).

Dioncopseudobenedenia ancoralis resembles Neobenedenia vermiculariocola Gupta et Khanna, 1975, listed as a species inquirenda by Whittington and Horton (1996). We could not obtain specimens of $N$. vermiculariocola. Dioncopseudobenedenia ancoralis and N. vermiculariocola have small, widely spaced testes, a broad muscular penis and a small haptor with a wide periphery invested with musculature. Siganus vermicularis Valenciennes, the host of $N$. vermiculariocola (see Gupta and Khanna 1975), is likely S. vermiculatus (Valenciennes) (see Froese and Pauly 2011), a congener of S. lineatus. It is possible that $D$. ancoralis and $N$. vermiculariocola are either synonyms or congeners.

\section{DISCUSSION}

Adult Dioncopseudobenedenia species have a single pair of median haptoral sclerites. Larval morphology of $D$. kala confirms that these are homologous with the accessory sclerites of other benedeniines. Adult Calicobenedenia polyprioni also has only one pair of median haptoral sclerites, but these are tiny (around $20 \mu \mathrm{m}$; Kritsky and Fennessy 1999), are more posterior on the haptor and most resemble posterior hamuli. In three of 11 specimens of $D$. ancoralis, one accessory sclerite was absent, and in four of 19 specimens of D. kala from Hawaii, one accessory sclerite was very small and misshapen. Ogawa et al. (1995b) noted similar deformities in the haptors of specimens of Neobenedenia and Deveney and Whittington (2010) highlighted similar deformities in accessory sclerites and hamuli in material of Benedenia fieldsi. 
Deveney, Whittington: Dioncopseudobenedenia spp. from Pacific fishes

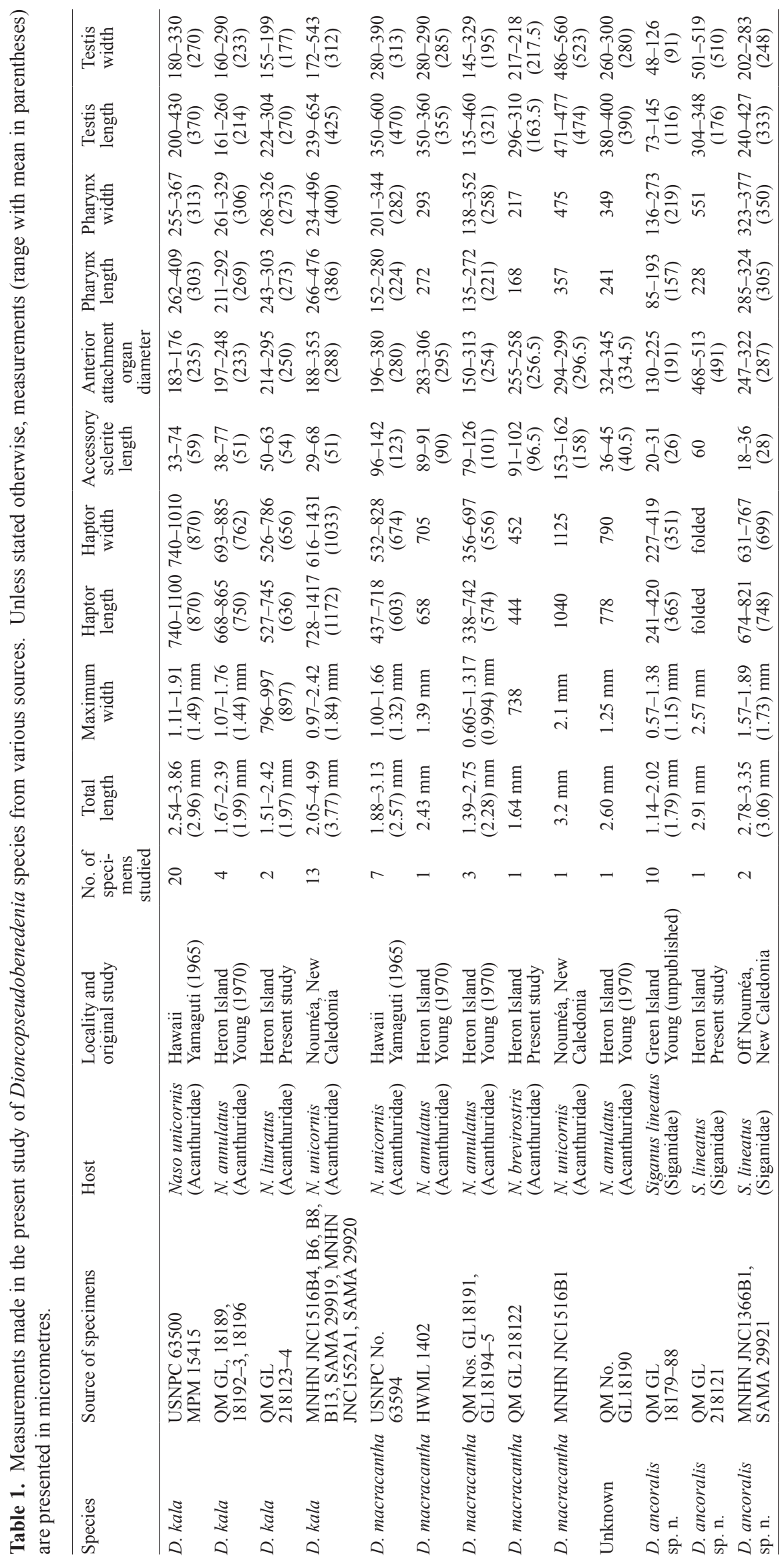


These abnormalities may be environmentally induced, perhaps caused by host immune responses. It is unclear, however, why deformities are common only in some benedeniine species.

How Dioncopseudobenedenia spp. attach is obscure; Entobdella soleae uses its accessory sclerites to generate suction (Kearn 1964, Whittington and Kearn 1991) but Dioncopseudobenedenia spp. lack tendons associated with the accessory sclerites. In $D$. kala and $D$. ancoralis, the accessory sclerites appear to play no role in attachment. In D. macracantha their function is unclear. Live specimens of $D$. kala and D. macracantha folded their haptor both transversely around primary gill lamellae as reported for Trochopus pini (van Beneden et Hesse, 1863) Massa, 1903 (see Kearn 1971) and Benedenia jaliscana Bravo-Hollis, 1952 (see Whittington et al. 2001) and longitudinally as reported for B. rohdei (as Benedenia sp. 1, see Whittington and Kearn 1991). Both species' haptors can generate suction: they were able to attach to glass with their haptor flat. Dioncopseudobenedenia ancoralis attaches to primary gill lamellae, gill arches, gill rakers and the inside of the operculum using the marginal loculi to generate suction and were more difficult to remove from their host than other benedeniines.

Dioncopseudobenedenia spp. are recorded from acanthuroid teleosts from Hawaii, the Great Barrier Reef and Nouméa, in the Pacific. This is the first record of a capsalid from an acanthuroid from New Caledonia (see Justine 2010). The Acanthuroidei, however, are distributed widely throughout the Indo-Pacific and these parasites may be more extensively distributed. Capsalids display a wide range of host-specificity patterns (Whittington 1996) and D. kala and D. macracantha share N. unicornis as a host in Hawaii and New Caledonia but are recorded from different host species at Heron Island. The causes of this phenomenon are unknown but Heron Island may represent the limit of the geographic range of these monogenean species.

Other fish in the Acanthuroidei also host capsalids. The type host of Oligoncobenedenia nasonis (Yamaguti, 1965) (Benedeniinae) is Naso hexacanthus Bleeker, and Benedenia hawaiiensis (Yamaguti, 1968) (Benedeniinae) is recorded from Acanthurus dussumieri Valenciennes in Cuvier and Valenciennes, A. nigrofuscus (Forsskål) and
Naso hexacanthus. Allometabenedeniella orbicularicola (Gupta et Khanna, 1975) Hussey, 1986, (Benedeniinae) Sprostoniella multitestis (Bychowsky et Nagibina, 1967) (Trochopodinae) and Sessilorbis limopharynx Mamaev, 1970 (Trochopodinae) parasitize Platax orbicularis Forsskål (Ephippidae). Platax pinnatus (L.) is also recorded as a host of Sprostoniella multitestis. Sprostoniella micrancyra Cezar, Luque et Amato, 1999 is recorded from Chaetodipterus faber (Brousonnet) and S. lamothei Pérez et Mendoza, 2000 parasitizes C. zonatus (Girard).

Dioncopseudobenedenia spp. occur at lower prevalence and intensity at Heron Island than other benedeniines such as Benedenia lutjani (see Whittington and Kearn 1993) and B. rohdei (see Whittington et al. 1994). Rohde and Hobbs (1988) commented that rarity can reflect high pathogenicity or an Allee effect. Parasite populations on coral reef fish may vary over small spatial scales (Grutter 1998, Cribb et al. 2000) but our sampling of potential hosts was limited. Rarity is an under-studied element in parasite ecology; further sampling and analysis of this host-parasite system could be useful in examining this phenomenon.

Acknowledgements. We are grateful to Professeur Jean-Lou Justine of MNHN for the use of his capsalid material from reef fish of New Caledonia. We thank Dr. Scott Gardner and Agustin Jiménez-Ruiz of HWML, Jimmy Cassone of MNHN, Dr. Jun Araki of MPM, Dr. Lester Cannon, Dr. Rob Adlard and Dr. Mal Bryant of QM, Dr. Leslie Chisholm of SAMA and Dr. J. Ralph Lichtenfels and Dr. Patricia Pilitt of USNPC for loan, use and acceptance of material. Fieldwork was greatly enriched by Dr. Tom Cribb, Dr. Sylvie Pichelin, Dr. Clinton Chambers, Dr. Alistair Dove, Dr. Rod Bray and Shelly Lachish, without whom the diversity of hosts examined in this study would have been limited. Anita Herzig assisted greatly with the creation of the figures. The Director and staff of the Heron Island Research Station of The University of Queensland (UQ) provided excellent facilities, support and assistance on the reef, for which we are grateful. SEM was done at the Centre for Microscopy and Microanalysis at UQ and we thank the Director and staff for assistance and access to facilities. Col Thomas serviced optical equipment during this study. An Australian Postgraduate Award supported MRD. This project was supported by Australian Research Council large grant No. A19600180 for 1996-1998 to IDW.

\section{REFERENCES}

Chisholm L.A., Whittington I.D. 1995: A revision of Dendromonocotyle Hargis, 1955 (Monogenea: Monocotylidae) with a description of a new species from Pastinachus sephen (Forsskål) (Myliobatiformes: Dasyatididae) from the Great Barrier Reef, Australia. J. Nat. Hist. 29: 1093-1119.

Chisholm L.A., Whittington I.D. 1999: A revision of the Merizocotylinae Johnston and Tiegs, 1922 (Monogenea: Monocotylidae) with descriptions of new species of Empruthotrema
Johnston and Tiegs, 1922 and Merizocotyle Cerfontaine, 1894. J. Nat. Hist. 33: 1-28.

Chisholm L.A., Whittington I.D. 2000: Heliocotyle ewingi sp. n. (Monogenea: Monocotylidae) from the gills of Myliobatis australis (Myliobatididae) from Tasmania, Australia. Folia Parasitol. 47: 100-104.

Cribb T.H., Anderson G.R., Dove A.D.M. 2000: Pomphorhynchus heronensis and restricted movement of Lutjanus carponotatus on the Great Barrier Reef. J. Helminthol. 74: 53-56. 
Deveney M.R., Whittington I.D. 2010: Three new species of Benedenia Diesing, 1858 from the Great Barrier Reef, Australia with a key to species of the genus. Zootaxa 2348: 1-22.

Froese R., Pauly D. (Eds.) 2011: FishBase. World Wide Web electronic publication, www.fishbase.org, version 02/2011, 14 May 2011.

Grutter A.S. 1998: Habitat-related differences in the abundance of parasites from a coral reef fish: an indication of the movement patterns of Hemigymnus melapterus. J. Fish Biol. 53: $49-57$.

Gupta N.K., Khanna M. 1975: On some of the monogenetic trematodes of marine fishes of Port Blair (Andaman and Nicobar Inslands, (sic) India). Part II. Rev. Ibér. Parasitol. 35: 3-23.

Horton M.A., Whittington I.D. 1994: A new species of Metabenedeniella (Monogenea: Capsalidae) from the dorsal fin of Diagramma pictum (Perciformes: Haemulidae) from the Great Barrier Reef, Australia with a revision of the genus. J. Parasitol. 80: 998-1007.

Justine J.-L. 2005: Species of Pseudorhabdosynochus Yamaguti, 1958 (Monogenea: Diplectanidae) from Epinephelus fasciatus and E. merra (Perciformes: Serranidae) off New Caledonia and other parts of the Indo-Pacific Ocean, with a comparison of measurements of specimens prepared using different methods, and a description of P. caledonicus n. sp. Syst. Parasitol. 62: $1-37$.

Justine J.-L. 2010: Parasites of coral reef fish: how much do we know? With a bibliography of fish parasites in New Caledonia. Belg. J. Zool. 140 (Suppl.): 155-190.

Kearn G.C. 1963: The egg, oncomiracidium and larval development of Entobdella soleae, a monogenean skin parasite of the common sole. Parasitology 53: 435-447.

Kearn G.C. 1964: The attachment of the monogenean Entobdella soleae to the skin of the common sole. Parasitology 54: 327-335.

KeARN G.C. 1970: The production, transfer and assimilation of spermatophores by Entobdella soleae, a monogenean skin parasite of the common sole. Parasitology 60: 301-311.

KeARN G.C. 1971: The attachment site, invasion route and larval development of Trochopus pini, a monogenean from the gills of Trigla hirundo. Parasitology 63: 513-525.

Kearn G.C., James R., Evans-Gowing R. 1993: Insemination and population density in Entobdella soleae, a monogenean skin parasite of the common sole, Solea solea. Int. J. Parasitol. 23: 891-899.

Kearn G.C., Ogawa K., Maeno Y. 1992: Egg production, the oncomiracidium and larval development of Benedenia seriolae, a skin parasite of the yellowtail, Seriola quinqueradiata, in Japan. Publ. Seto Mar. Biol. Lab. 35: 351-362.

Kearn G.C., Whittington I.D. 1992: Diversity of reproductive behaviour in platyhelminth parasites: insemination in some benedeniine (capsalid) monogeneans. Parasitology 104: 489496.

Kearn G.C., Whittington I.D. 2005: Neoentobdella gen. nov. for species of Entobdella Blainville in Lamarck, 1818 (Monogenea, Capsalidae, Entobdellinae) from stingray hosts, with descriptions of two new species. Acta Parasitol. 50: 32-48.

Kearn G.C., Whittington I.D., Euzet L. 2006: The handling and fate of spermatophores in Neoentobdella diadema and N. apiocolpos (Monogenea: Capsalidae: Entobdellinae). Folia Parasitol. 53: 57-62.

Kritsky D.C., Fennessy C.J. 1999: Calicobenedenia polyprioni n. gen., n. sp. (Monogenoidea: Capsalidae) from the external surfaces of wreckfish, Polyprion americanus (Teleostei: Polyprionidae), in the North Atlantic. J. Parasitol. 85: 192-195.
Neifar L., Euzet L., Ben Hassine O.K. 1999: Heliocotyle kartasi gen. et sp. n. (Monogenea: Monocotylidae) parasitic on Pteromylaeus bovinus (Euselachii: Myliobatinae) from Tunisia. Folia Parasitol. 46: 29-32.

Nelson J.S. 2006: Fishes of the World. Fourth Edn. Wiley, New York, $601 \mathrm{pp}$.

Ogawa K., Bondad-Reantaso M.G., Fukudome M., WakabaYASHI H. 1995b: Neobenedenia girellae (Hargis, 1955) Yamaguti, 1963 (Monogenea: Capsalidae) from cultured marine fishes of Japan. J. Parasitol. 81: 223-227.

Ogawa K., Bondad-Reantaso M.G., Wakabayashi H. 1995a: Redescription of Benedenia epinepheli (Yamaguti, 1937) Meserve, 1938 (Monogenea: Capsalidae) from cultured and aquarium marine fishes of Japan. Can. J. Fish. Aquat. Sci. 52 (Suppl. 1): $62-70$.

Pérez-Ponce De León G., Mendoza-Garfias B. 2000: A new species of Sprostoniella Bychowsky and Nagibina, 1967 (Monogenea: Capsalidae) from Chaetodipterus zonatus (Osteichthyes: Ephippidae) in Chaemela Bay, Mexico. J. Parasitol. 86: 811-814

Perkins E.M., Donnellan S.C., Bertozzi T., Chisholm L.A., Whittington I.D. 2009: Looks can deceive: molecular phylogeny of a family of flatworm ectoparasites (Monogenea: Capsalidae) does not reflect current morphological classification. Mol. Phylogen. Evol. 52: 705-714.

Randall J.E., Allen G.R., Steene R.C. 1997: The Complete Divers' and Fishermen's Guide to Fishes of the Great Barrier Reef and Coral Sea. Second Edn. Crawford House, Bathurst, $557 \mathrm{pp}$.

Rohde K., Hobbs R. 1988: Rarity in marine Monogenea. Does an Allee-effect or parasite-induced mortality explain truncated frequency distributions? Biol. Zentralbl. 107: 327-338.

Whittington I.D. 1996: Benedeniine (capsalid) monogeneans from Australian fishes: pathogenic species, site-specificity and camouflage. J. Helminthol. 70: 177-184.

Whittington I.D. 2010: Revision of Benedeniella Johnston, 1929 (Monogenea: Capsalidae), its assignment to Entobdellinae Bychowsky, 1957 and comments on subfamilial composition. Zootaxa 2519: 1-30.

Whittington I.D., Barton D.P. 1990: A new genus of monogenean parasites (Capsalidae: Benedeniinae) from stingrays (Rajiformes: Dasyatidae) with a description of a new species from the long-tailed stingray Himantura uarnak Forsskål from Queensland, Australia. J. Nat. Hist. 24: 327-340.

Whittington I.D., Deveney M.R.: New Benedenia species (Monogenea: Capsalidae) from Diagramma labiosum (Perciformes: Haemulidae) on the Great Barrier Reef, Australia, with oncomiracidial descriptions and a report of egg attachment to the host. J. Parasitol. (In press.)

Whittington I.D., Deveney M.R., Wyborn S.J. 2001: A revision of Benedenia Diesing, 1858 including a redescription of B. sciaenae (van Beneden, 1858) Odhner, 1905 and recognition of Menziesia Gibson, 1976 (Monogenea: Capsalidae). J. Nat. Hist. 35: 663-777.

Whittington I.D., Horton M.A. 1996: A revision of Neobenedenia Yamaguti, 1963 (Monogenea: Capsalidae) including a redescription of N. melleni (MacCallum, 1927) Yamaguti, 1963. J. Nat. Hist. 30: 1113-1156.

Whittington I.D., Kearn G.C. 1991: The adhesive attitudes of some gill-parasitic capsalid monogeneans. J. Helminthol. 65: $280-285$

Whittington I.D., Kearn G.C. 1993: A new species of skin-parasitic benedeniine monogenean, with a preference for the pelvic 
fins of its host, Lutjanus carponotatus (Perciformes: Lutjanidae) from the Great Barrier Reef. J. Nat. Hist. 27: 1-14.

Whittington I.D., Kearn G.C. 2009a: Two new species of entobdelline skin parasites (Monogenea, Capsalidae) from the blotched fantail ray, Taeniura meyeni, in the Pacific Ocean, with comments on spermatophores and the male copulatory apparatus. Acta Parasitol. 54: 12-21.

Whittington I.D., Kearn G.C. 2009b: Two new species of Neoentobdella (Monogenea: Capsalidae: Entobdellinae) from the skin of Australian stingrays (Dasyatidae). Folia Parasitol. 56: $29-35$.

Whittington I.D., Kearn G.C., Beverley-Burton M. 1994: Benedenia rohdei n. sp. (Monogenea: Capsalidae) from the gills of Lutjanus carponotatus (Perciformes: Lutjanidae) from

Received 15 May 2011
The Great Barrier Reef, Queensland, Australia, with a description of the oncomiracidium. Syst. Parasitol. 28: 5-13.

Yamaguti S. 1965: New monogenetic trematodes from Hawaiian fishes. I. Pac. Sci. 19: 55-95.

Yamaguti S. 1966: New monogenetic trematodes from Hawaiian fishes. II. Pac. Sci. 20: 419-434.

Yamaguti S. 1968: Monogenetic Trematodes of Hawaiian Fishes. University of Hawaii Press, Honolulu, 287 pp.

Young P.C. 1967: A taxonomic revision of the subfamilies Monocotylinae Gamble, 1896 and Dendromonocotylinae Hargis, 1955 (Monogenoidea: Monocotylidae). J. Zool., Lond. 153: 381-422.

Young P.C. 1970: The species of Monogenoidea recorded from Australian fishes and notes on their zoogeography. An. Inst. Biol. Univ. Nat. Autón., México 41, Ser. Zool. 1: 163-176.

Accepted 27 June 2011 